\title{
Social Media Marketing: Gateway to Success for Homepreneurs
}

\author{
Vishwas Iresh Swami, Deepa Naidu
}

\begin{abstract}
As stated by the International Labour Organization (ILO), unemployment rate in India was at $3.5 \%$ in 2018 and 18.9 million people were jobless. The government of India constantly motivates its citizens to become entrepreneurs and create employment opportunities for others by launching programs like start up India, mudra bank, fund of funds and many others. As per the Indian government data, Micro, Small and Medium Enterprises (MSME) contribute nearly 8 percent of the country's $G D P$ which reflects they play a significant role in the country's GDP. Each year, thousands of determined entrepreneurs start new businesses however only handful of them survives and plenty of small business are gone by the end of four years of their establishment. The major reason behind business failures are lack of experience, insufficient capital and poor location. Entrepreneurship is so dynamic in nature that it gives plausible solution for all potential entrepreneurs out there. One of the solutions for budding entrepreneurs is becoming a homepreneur. Homepreneurs are business entrepreneurs operating from their home. They are managing their business operations from home. It is a splendid opportunity for those who want to start something new without investing huge capital and taking bigger risks. The question arises is how do they attract their target audience without investing larger amount and time to meet them. One of the answers to this question is social media. Social media are interactive websites and applications that are designed to allow people to share content quickly, effectively and real time. Social media channels and online marketplaces have made it simple for homepreneurs to reach new audience, deliver products and receive payments. Platforms like Face book, Instagram, Watsapp, YouTube, Twitter, Google Ad, Mobikwik and various other applications are useful for marketing. Almost every individual is connected on one of above mentioned platforms. Social media has changed the face of marketing and completely taken communication, advertising and online marketing to the next level. The researcher will use phenomenology as the method of research. This research paper will explain the concept of homepreneurs; will put a light on various social media platforms for homepreneurs; will talk about their advantages and highlight its working. It will also share many examples of homepreneurs actively participating on these platforms and achieving success. This will definitely help the group who want to start a small business to understand the framework of homepreneurship and functional for those who want to expand their business operation online. As said by late prime minister Atal Bihari Vajpayee "Empowering the individual means empowering the nation. And empowerment is best served through rapid economic growth with rapid social change". Entrepreneurship is pivotal for individual empowerment, economic growth and sustainable development.
\end{abstract}

Keywords: Entrepreneurs, Homepreneurs, Economic Growth

Revised Manuscript Received on March 2, 2020. Corresponding Authors:

Ms.Deepa Naidu*,Research Scholar,BMCC, d.deepanaidu @ gmail.com Commerce, Pune, Maharashtra. Dr. Vishwas Iresh Swami, HOD of BBA department in Sinhgad College of

\section{INTRODUCTION}

Entrepreneurs are crown jewels for nation's growth and prosperity. They nurture, protect and encourage entrepreneurs. In the history of Indian civilization, entrepreneurship has seen many crests and troughs. Handicrafts and craftsmanship were art and artisans in India flourished. Soon British colonial government brought in various changes in Indian economy and the face of entrepreneurship changed. Post independence, government of India made huge changes in the policies to become self-regulating and for countries growth. It's been 73 years of independence and India is promoting entrepreneurship rigorously. It is a known fact that entrepreneurs have a significant role in the economic development, they explore ideas \& opportunities and convert it into business ventures by establishing new industries to avail these opportunities. Lack of entrepreneurs in a country is the main obstacle of economic development. The Indian government recognizes this fact and has been bullish about the boost of entrepreneurial ecosystem in India. Prime Minister Narendra Modi in his speech said startups are growth engines for the country and urged the people of India to keep innovating. Programs like Start up India, Mudra Bank, Make in India, and Fund of funds are all examples of government initiatives. While India has seen numerous success stories from its start-up ecosystem but at the same time, there have also been many tales of failure. As per the study done by IBM Institute for Business Value and Oxford Economics named "Entrepreneurial India," it was found that, in India, 90\% of startups fail during the first five years. According to Bloomberg, businesses fail within 18 months for 8 out of 10 entrepreneurs. Most common reason for failure is lack of innovation, lack of skilled workforce, inadequate funding, insufficient formal mentoring, poor business ethics, and lack of experience, insufficient capital and poor location.

Running a profitable business takes plenty of skills, research work, extensive experience and professional know-how. One of the solutions for budding entrepreneurs is becoming a homepreneur. Homepreneurs are business entrepreneur who operates from his or her home. Homepreneurs can utilize any spare room or available area as an office to operate business activities. Becoming a homepreneur is an excellent approach to start small and earn entrepreneurial skills, do systematic and thorough research, gain experience and learn entrepreneurial qualities.

This will be one of the suitable alternatives for those budding entrepreneurs who want to start small without investing huge capital \& resources, avoid high risks and achieve a good sense of entrepreneurship by thorough practice and put effort to gain entrepreneurial

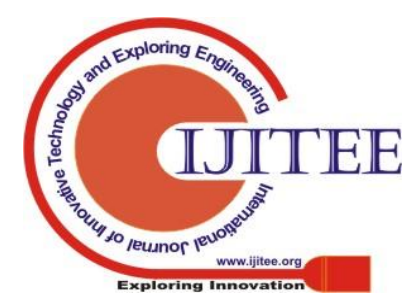


qualities. Presence of homepreneurs can be seen since ancient times. Today it has identified as a feasible career option for those various budding entrepreneurs with different motivating factors to become homepreneurs. Homepreneurs have to exercise multiple management practices to run a successful business. Role of a homepreneur is diverse and challenging which entitles an individual to work from home however dedicates time and focus excluding the distractions and commitments at home. One of the challenges would be marketing practices. Homepreneurs are operating the business from home, which means they have not selected the location as per target market but have a crucial job to attract the audience towards the product/service. This is a critical challenge as many businesses fail to succeed in marketing aspect simply because they fail reach and convince the audience. Marketing is dynamic in nature and differs as per the need and expertise of the business. Revolution in digital marketing has changed the view of how anyone who would overlook marketing, becoming the necessity for any business. Digital marketing is marketing of products/services online, also referred as internet marketing. Digital marketing was more refined in the 2000s and the 2010s. Prime Minister Narendra Modi has nudged the country to move towards digitization with Digital India programme. As consumers become user friendly with digital electronics, using internet and electronic devises daily, they expected product / service information to be available across different channels and this very change in the behavior enhanced diversification of digital marketing. Digital Marketing also made way for Social Media Marketing. Social media is the platform which enables people to share idea, thought or content quickly and efficiently with the help of websites and applications through computers, smart phones or tablets. With the development of social media in the 2000s, consumers rapidly started using websites and applications such as Face book, Instagram, YouTube, Watsapp, LinkedIn, Twitter and many more. Entrepreneurs are known to exploit every single opportunity therefore it doesn't come as a surprise as they jumped on this platform to reach their customers. Social media marketing is godsend for homepreneurs. It is the perfect prospect for them to reach their customers. Not only it allows them to speak to their customers, but also helps to understand their exact need, receive payments, deliver the product, track orders, analyze customer satisfaction, take feedback, manage schedules, monitor financial transactions \& accounts and keep a track of expenses. There are hundreds of applications suitable for each and every necessity.

\section{OBJECTIVES}

1. To study the concept of homepreneurs.

2. To understand the importance of homepreneurs.

3 . To assess the advantages of social media marketing.

4. To study the case studies of homepreneurs.

\section{RESEARCH METHODOLOGY}

The study is descriptive type. The researcher has used case study research method and phenomenology as the method of research and studied the interviews, discussions, online presentations of homepreneurs which are available on Youtube, print media and websites. The researcher studied 4 such entrepreneur from each of these online cases along with 4 entrepreneurial case studies available on print media.

\section{WORKING DEFINITIONS}

Entrepreneur - Entrepreneur is a person, who attempts to create something new, organizes production activities and undertakes risks and handles uncertain challenges involved in the enterprise.

Homepreneurs - Homepreneurs is defined as a business owner doing business from home. Homepreneurs are entrepreneurs who carry out business from their home.

Homepreneurship - Homepreneurship is the process of identifying opportunities, arranging the resources required to pursue these opportunities and follow through business from home.

Digital Marketing - Digital marketing can be defined as marketing of products or services using digital technologies. Social Media Marketing - Social media marketing is the use of social media platforms, applications and websites to promote a product or service.

\section{HOMEPRENEURS}

Homepreneurs are business entrepreneur who operates from his or her home. Collins dictionary defines homepreneurs as "an entrepreneur who creates and manages a home based business". Though there is no formal definition by the government but it can understood that homepreneurs manage their business operations from home. They can utilize any spare room, kitchen, garage, living room or available area as an office to operate business activities. This is a great prospect for those with limited resources, to work with reduced operating expenses, test and incubate their products and services, reduce the risk in investment and save time and money by not having to commute to work. It also gives homepreneurs the space to work in a safe environment, especially for women. Also helpful for those individuals who want to maintain a flexible working schedule to adjust with their household and family needs and keep a successful work and home balance.

\section{A. Importance of homepreneurs}

They are critical element for economic growth and development. It enables unemployed individual to become self employed, to establish small businesses and earn their livelihood. Homepreneurs create employment chances for others. Also, most common reason for failure is lack of innovation. By choosing to become homepreneur, they have an opening to check if their idea can be fully transformed into opportunity and to run a business from their homes under reduced expenses. Homepreneurs can test their product/service and market before investing in a larger business. Critically, it also facilitates more informal-sector entrepreneurs to shift to the formal and therefore into an organized economic market, which is important for government and economic growth.

\section{B. Qualities of Homepreneurs}

Characteristics of homepreneurs are no different than the essentials for entrepreneurs. Homepreneurs are driven individuals with a business 
idea; they are disciplined and focused on their business work. They are confident and knowledgeable to make their businesses succeed. They are innovative; they analyze every event and situation to proceed vigilantly. Homepreneurs are creative; they use their resources effectively and come up with solution for every bottleneck. Homepreneurs are always multi tasking, they are skilled with efficient management practices, they utilize the available resources, whether it is time, space, raw material or money, they efficiently consume the resources with zero wastage. Homepreneurs are risk takers. It's not about taking just any risk, but calculated risks that will pay off which is an important aspect of homepreneur. Homepreneurs are customer oriented. They understand the importance of customer satisfaction and which therefore drives them to maintain fine quality product and service. Finally, homepreneurs are passionate. Their business is the extension of their personality, ethics and this is what helps them to be self motivated and drives them forward.

\section{SOCIAL MEDIA MARKETING FOR HOMEPRENEURS}

Social media are a computer-mediated technology which facilitates to share information, ideas, views, career interests and other forms of communication to allow users to participate in social networking. Social media marketing is the use of social media platforms, applications and websites to promote a product or service. It helps millions of marketers \& customers to connect generate awareness and increase sales. There are thousands of applications and websites which assist individual to learn every aspect of business. Homepreneurs connect to customers via these websites to sell the product/service, deliver the product, track orders, analyze customer satisfaction, take feedback and receive payments.

These websites and applications helps to connect with the customers, share the information of the product/service in form of chats, photos and videos, modify the product /service as per the need of customer, take online payments and deliver the product/service to customer's door step. Face book is such a diverse platform where marketers create their business page and post their business details and product / service information. Groups are formed on face book, most famous example is PULA. It is a social media interactive platform created for Pune Ladies. Their vision is to create a 'Female-Family' for fellow females in Pune to allow them to post their business details so that customers can contact them. Watsapp is another amazing platform where owners can create groups and chat with the group of potentials customers and connect with everyone. WhatsApp bubble pop-up feature can be used to share the 'Buy Now' links with the WhatsApp contact or groups. Twitter is a platform that allows brands and users to communicate via short messages — also known as "tweets." Instagram allows users to share photos and videos, and even hosts live streaming capabilities. Homepreneurs selling on Instagram can link their accounts so that when potential buyers express interest in a product but don't buy it immediately; they can be contacted via different modes of communication and be reminded about the product they enquired about on Instagram. Websites like Face book, Watsapp, Instagram, Youtube, QQ, WeChat, QZone, Tumblr, Twitter, Skype, Snapchat, Pinterest, LinkedIn, Reddit, $\quad$ Foursquare, MySpace, StumbleUpon, the-dots.com, Messenger, BizSuger are great platform to connect with people, advertise and promote brands. Applications like Paytm, Mobiwik, Googlepay, PayPal, and Payzapp are useful to send and receive payments. Applications like Dunzo, Pyck and Pickrr focus on delivery of items. Each and every website and application is unique in usage, applicability and has advantages if used appropriately. Social media websites have millions of users and every individual is connected via one of these platforms.

Social media marketing increases brand recognition as it helps to engage with a broad audience. With increased visibility, businesses gain more opportunities for conversion. Social media helps to gain customer satisfaction. It gives a chance to understand the customers need and promotes better communication. Being able to acknowledge each customers comment shows attentiveness and aim to provide the best experience. Social media allows addressing any question or complaining using interpersonal dialogue. Regularly interacting with customers demonstrates that business cares about customer satisfaction and tends to improve brand loyalty. Having customers mention business name on social media websites will advertise business, and show new visitors value and brand authority. Social media marketing is the most cost-efficient advertising strategy. To Sign up on and create a profile is free for about all social networking platforms. Cost-effectiveness means greater returns on investment and bigger budget for other business expenses

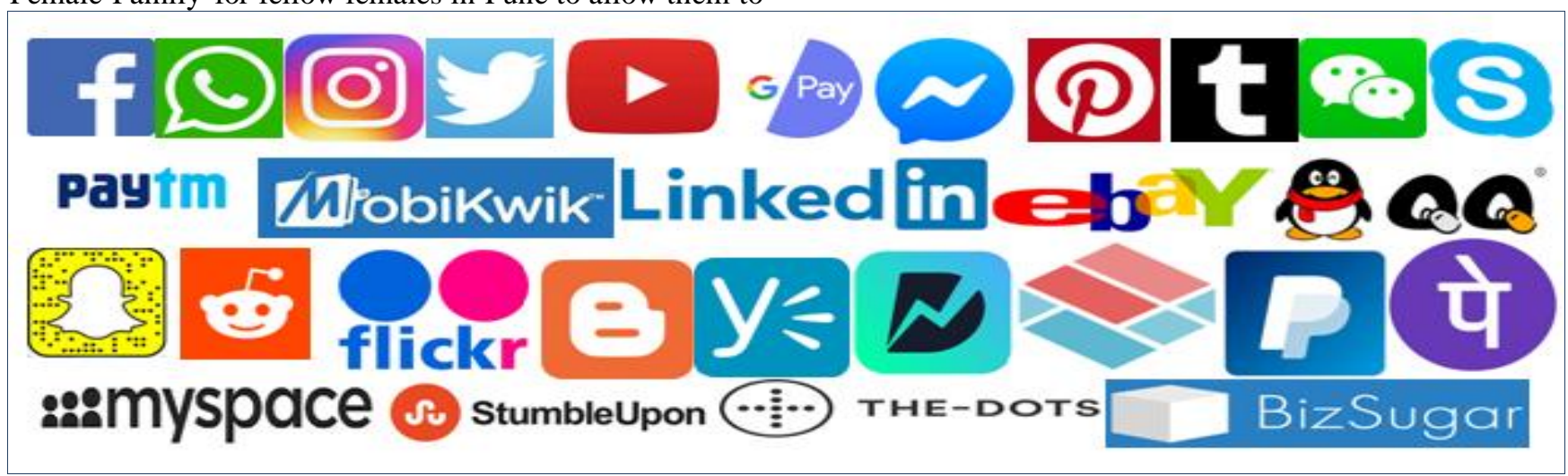




\section{CASE STUDIES}

1. Priyanka Gusain: Priyanka Gusain completed her Bachelor degree in Commerce in 2012. She is an artist and sells hand-crafted and painted shoes, jackets, scarves, wallets and clutches. Started in 2013, she had a budget of ₹50,000 to start the business, most of which was spent in purchasing the raw material. Since there was no money for marketing, she tried the social media route and used Face book for promotion and queries. Using software as a service (SaaS) via KartRocket, she created a website Zubiya.com. It is an inexpensive way to launch and has in-built payment options, brand-building and logistical support. She had a passion for fine arts and wanted her brand to reflect that fervor for colors and quirky patterns. All products are hand-painted and designed by Priyanka, with employment of local village tailors to stitch the fabrics which aids in their livelihood sustenance. Footwear is hand-painted with waterproof acrylic colours. Products sold by Priyanka are handmade and unique. Priyanka has face book page named Crafted by Zubiya, with various product information and LinkedIn Page where she post updates regarding latest collections. Social media and digital marketing enables her to pursue her dreams and create Zubiya.

2. Rakshita Dwivedi: She is social media consultant and has over 10 years of experience in HR panning Talent Management to Employee Engagement and HR automation. Life \& Money was launched in the year 2013 to empower millennia's to live their dreams. They create financial wellness programs to assist participants in understanding the role of financial wellness in their lives, to build smart money management techniques and develop financial planning skills. Rakshita runs a lovely venture Recipe Dabba. It was launched in 2017, inspiring people for healthy choices and offer programs and products around helping the families adapt change which helps in adapting healthy food choices early and motivating clients to stay healthy. Rakshita says she uses social media to reach out to her audience, for community building, and for lead generation and marketing. She is a part of several online communities where she can communicate with prospective clients. She mentions Face book generates the maximum leads for her, but she uses Instagram for branding because of the visual effect it provides. For marketing, she also uses WhatsApp. She started putting recipe videos online as WhatsApp status and broadcast messages on multiple WhatsApp groups. Rakshita has a very active LinkedIn page with articles related to Recipe Dabba. She also has a face book page Recipe Dabba with easy and healthy recipe videos and photos. Rakshita is a recipient of 'Homepreneur Awards' by Brand Avataar, 'Made by Her Award' by Woman at Work, 'Orange Flower Award' by Women's Web.

3. Tarika Jain: Tarika Jain was living in Switzerland with her husband and her 5-year-old son. She used to bake eggless cakes as hobby. She continued even after she shifted to Bengaluru five year ago. What started as a hobby soon turned into a regular affair after repeated requests from family and friends to bake cake on special occasions. Now working from home, she bakes and delivers customized cakes to people in Bengaluru. Apart from the cake, she also arranges sweet table using cupcakes, cake pops and other desert items. She turned it into a platform called Sweet Delight, created a face book page and started posting pictures. Tarika didn't give much thought about money when she decided to bake. She started by creating a Face book page and posting pictures of the cakes on it and within a year she started getting orders. She runs her business only through Face book and Watsapp. Tarika successfully utilized social media platform to start the business venture 'Sweet Delight' and runs it as a one-woman show.

4. Priya Harjai: Priya Harjai was born and raised in Mumbai. She was a web designer for 12 years before choosing to quit her job for motherhood. She didn't want to be a homemaker and was interested in art \& craft. She creates handmade designer wooden boxes, jewelry boxes and multipurpose gift boxes. Each box is beautifully designed and a piece of art on its own. She started Olive by Design in 2015 via Shopmatic. While the offline store got 25 orders a month, queries from prospective buyers increased after she launched the e-store.

5. Indrajeet Jaiwan: Indrajeet came to Pune to pursue her professional career in corporate field however her love for fashion inspired her to become a homepreneur. She created ThePitaara in 2017. The website offers large variety of accessories, jewelries, purses, shoes and many more. She also has a face book and Instagram page with photos of variety of products available and communicates with customers. She actively works on her social media page and interacts with them.

6. Zahra Khan: Zahra Khan was born and raised in Pune. She is a professional makeup artist, hairstylist, fashion stylist and got certified from VLCC and L'Oreal. Her passion for makeup and fashion inspired her to become homepreneur. She has a parlor setup in a spare room at home. It is beautifully designed and has all the facilities available. She has gained loyal customers via Instragram. She posts photos $\&$ videos of her work on Instragram and attracts customers online. She also creates homemade shampoos, unique per customers need and demand. She even uses GooglePay and Paytm for payment transactions.

7. Aileen Xu: Aileen is a content creator, youtuber and blogger. She created a Youtube channel named Lavendaire in 2014 where she posts videos related to personal growth, lifestyle, travel, knowledge and inspiration on creating a dream life. Thousands of followers on Lavendaire eagerly await Aileen's content on Youtube. Most of the videos have millions of views. She also creates podcasts on personal growth and development. Her website also has Lavendaire Shop where viewers can purchase Artist of Life workbook journals to help customers create most successful year. 
These journals are filled with questions and exercises deigned to guide through self discovery fulfillment in life. Aileen has content spread out for viewers in social media websites like Instagram, Face book, Twitter, Weibo, Pinterest and Spotify to reach maximum number of viewers.

8. Kabita Singh: Kabita Singh is youtuber and blogger. She created Kabitas kitchen channel in 2014. Her intention was to create and post recipe videos which are simple to recreate and can be made with the readily available ingredients. Her channel primarily focuses on Indian cuisine. Kabita has more than 5 million followers on Youtube and has more than 8 million viewers watch her videos. She even has video sponsors and promotes their products. She keeps connected with her viewers on social platforms Instagram, Face book, Twitter and Pinterest.

\section{CONCLUSIONS AND SUGGESTIONS}

As per United Nations Development Programme (UNDP), unemployment rate was $5 \%$ estimated 172 million people worldwide were without work in 2018. Sustainable Development Goals encourage sustained economic growth, Increase levels of productivity and innovation in technology. They encourage entrepreneurship and consider job creation as effective measures to eradicate forced labour. Homepreneurship is the chance for all those individuals who want to start small and earn entrepreneurial skills, do systematic and thorough research, gain experience and learn entrepreneurial qualities. Homepreneurs are their own bosses and create job opportunities Digital marketing and social media marketing is gateways to success for homepreneurs. Social media marketing has gained relevance due to the growing influence of social media. Social media channels and online marketplaces have made it simple for homepreneurs to showcase their products, reach new audiences, deliver product and receive payment. Homepreneurs are suggested to skill themselves to use popular social interactive networks to better connect with the audience, understand their motives and preferences, with the intention of converting the interaction into sales. Homepreneurs should invest time to learn how they can benefit from these platforms, which websites and applications are suitable for their business type and engage accordingly. They can even hire social media experts in initial stage and take their expertise to create welcoming business pages on these platforms. Homepreneurs are extravagantly leveraging this opportunity to enhance their digital network making selling more fun and engaging. Social media is surely the way forward for the ambitious brands and homepreneurs of today. It is said that country is empowered when the people living in it are empowered. Financial empowerment enables people to become strong, confident and responsible and lead a self determined life, which will lead the nation towards economic growth and sustainable development.

\section{REFERENCES}

1. International Labour Organization, Statistics and Database, retrieved from https://www.ilo.org/global/lang--en/index.htm

2. United Nations Development Programme, Sustainable Development Goals, Decent Work and Economic growth, retrieved from https://www.undp.org/content/undp/en/home/sustainable-developmentgoals/goal-8-decent-work-and-economic-growth.html

3. Collins Dictionary, retrieved from https://www.collinsdictionary.com/submission/7872/Homepreneur

4. Forbes, Innovation, Suparna Dutt D'Cunha, May 18, 2017, retrieved from

https://www.forbes.com/sites/suparnadutt/2017/05/18/startups-in-india -fail-due-lack-of-innovation-according-to-a-new-ibm-study/\#36da0dc7 $\underline{657 \mathrm{~b}}$

5. $\overline{\text { Under }} 30 \quad \mathrm{CEO}, \quad$ retrieved from https://www.under30ceo.com/10-qualities-of-a-successful-entrepreneur l

6. The Times of India, Start Ups, Trend Tracking, Shubra Pant, December 17, 2017, retrieved from https://timesofindia.indiatimes.com/trend-tracking/homepreneurs-social -media-ecomm/articleshow/62095397.cms

7. The Economic times, Wealth, Earn, Chandralekha Mukerji, May 07, 2016, retrieved from https://economictimes.indiatimes.com/wealth/earn/homepreneurs-settin g-up-ecommerce-shops-to-scale-up-businesses/articleshow/51286711.c ms?from $=\mathrm{mdr}$

8. Search Engine Land Guide, retrieved from https://searchengineland.com/guide/what-is-social-media-marketing

9. Kabita Singh, Kabita's Kitchen, retrieved from https://www.youtube.com/channel/UCChqsCRFePrkyAA

10. Aileen $\mathrm{Xu}$, Lavendaire Channel, retrieved from https://www.youtube.com/user/Lavendaire

\section{AUTHORS PROFILE}

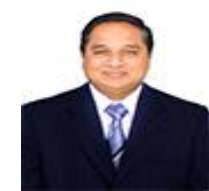

Dr. Vishwas Iresh Swami, HOD of BBA department in Sinhgad College of Commerce, Pune, Maharashtra.

Qualification: B.Sc. M.B.A, M.Phil, Ph. D.

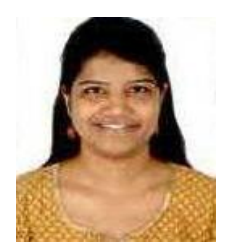

Ms. Deepa Naidu, Research Scholar from Brihan Maharashtra College of Commerce, Pune, Maharashtra.

Qualification: B.Com, M.Phil. 